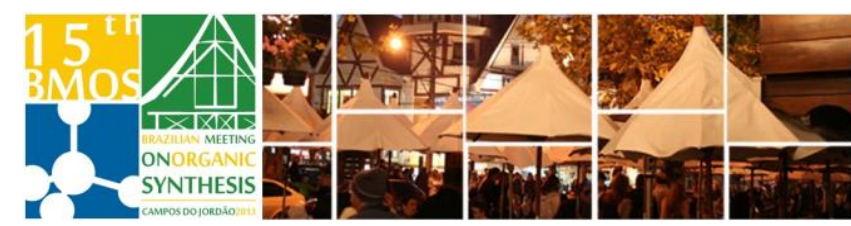

\title{
Oxireduction's Studies of Arytetralone and Aryltetralol Mediated by Rhodotorula sp
}

\author{
Marina G. Capeletto ${ }^{a^{*}}$, Luiz S. Longo Jra ${ }^{a}$, Wagner L. Batista ${ }^{a}$, Graziela G. Bianco \\ a Universidade Federal de São Paulo - Instituto de Ciências Ambientais, Químicas e Farmacêuticas (ICAQF) \\ Diadema, São Paulo, Brasil. \\ *capelettomari@bol.com.br
}

Keywords: aryltetralone, aryltetralol, oxireduction

\section{NTRODUCTION}

The Aristolochiaceae family presented extracts with antimalarial activity. Some aryltetralones lignans were isolated from Holostylis reniformis (Figure 1) and those are responsible for this antimalarical activity. 1,2

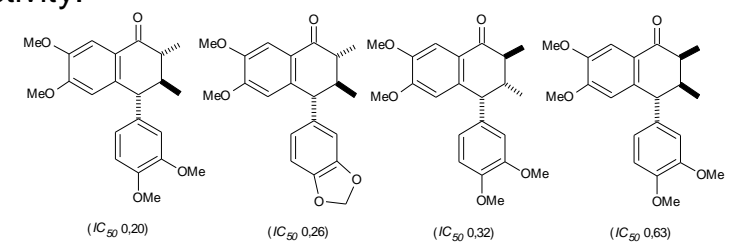

Figure 1: Aryltetralones isolated from Holostylis reniformis.

Biocatalysis has been shown to be a strong strategy to obtain enantiomerically pure substances, because it promotes reactions with high chemo-, regio- and stereoseletivity. $^{3}$

This methodology show to be important because it's environmentally favorable, since various principles of Green Chemistry may be contemplated like possibility of using water as a solvent, especially when we using whole cells. These whole cells contain all necessary cofactors to promote the desired reaction and they are able to recycle them. ${ }^{4,5}$

\section{RESULTS AND DISCUSSION}

The aryltetralone (1) was synthesized by a FriedelCrafts' reaction between $\alpha$-naphthol and benzene, in the presence of $\mathrm{AlCl}_{3}{ }^{6}$. The aryltetralol (2) was obtained by reduction of $( \pm)-1$ with $\mathrm{NaBH}_{4}$ and $\mathrm{MeOH}^{7}$ (Scheme 1).

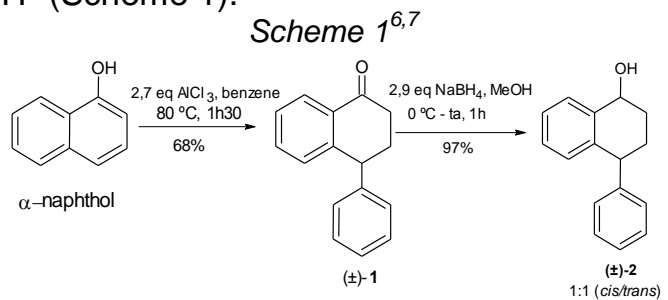

The $( \pm)-1$ and $( \pm)-2$ were submitted to reactions with Rhodotorula sp. This yeast was able to reduce $\alpha$ tetralones with a substituent in 4-position. ${ }^{8}$ The results are shown in Table 1 . The bioreduction reactions occur with $R$ hodotorula sp, but the amount formed wasn't sufficient to be isolated, except in YPD. A higher yield was found in $24 \mathrm{~h}$ (Entry 4). The formation of both alcohols, cis-2 and trans-2, occurred, except in $44 \mathrm{~h}$ in PBS (Entry 2).

The bio-oxidation reaction of $( \pm)-2$ occurs and it seems more promising than bioreduction because the isolation of $\mathbf{1}$, using column chromatography, was possible.

Table 1: Results of Reactions with Rhodotorula sp. ${ }^{\text {a }}$

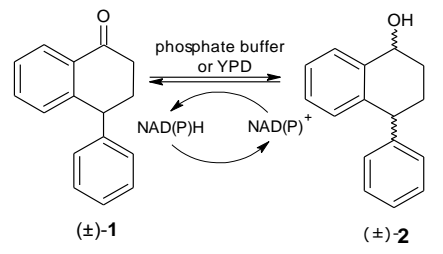

\begin{tabular}{|c|c|c|c|}
\hline Entry & Compound & Time & Cromatogram (\%) \\
\hline 1 & \multirow{5}{*}{$( \pm)-1$} & $22 \mathrm{~h}$ & $\begin{array}{c}\mathbf{1}(32 \%) \\
\text { cis-2 }(1 \%) \\
\text { trans-2(3\%) }\end{array}$ \\
\hline 2 & & $44 \mathrm{~h}$ & $\begin{array}{c}\mathbf{1}(46 \%) \\
\text { trans-2(1\%) }\end{array}$ \\
\hline $3^{b}$ & & $8 \mathrm{~h}$ & $\begin{array}{c}\mathbf{1}(30 \%) \\
\text { cis-2 }(12 \%) \\
\text { trans-2 }(10 \%)\end{array}$ \\
\hline $4^{b}$ & & $24 \mathrm{~h}$ & $\begin{array}{c}\mathbf{1}(39 \%) \\
\text { cis-2 }(18 \%) \\
\text { trans-2 } 22 \%)\end{array}$ \\
\hline $5^{b}$ & & $48 \mathrm{~h}$ & $\begin{array}{c}\mathbf{1}(62 \%) \\
\text { cis-2 }(7 \%) \\
\text { trans-2 }(11 \%)\end{array}$ \\
\hline $6^{b}$ & $( \pm)-2$ & $24 \mathrm{~h}$ & $\begin{array}{c}\mathbf{1}(28 \%) \\
\text { cis-2 }(55 \%) \\
\text { trans-2 }(17 \%)\end{array}$ \\
\hline
\end{tabular}

Reagents and Condictions: ${ }^{\mathrm{a}}$ Growth: $250 \mathrm{~mL}$ of YPD - Yeast ExtractPeptone-Dextrose Broth $(\mathrm{pH}=6,5 \pm 0,2), 150 \mathrm{rpm}, 26 \stackrel{\circ}{\circ} \mathrm{C}, 24 \mathrm{~h}$ or $48 \mathrm{~h}$. Yeast mass: $40 \mathrm{~mL}$ of YPD centrifuged at $1200 \mathrm{rpm}, 5$ minutes, $25{ }^{\circ} \mathrm{C}$. Reaction: $40 \mathrm{~mL}$ PBS - Phosphate Buffered Saline or YPD, yeast mass, 0,4 mmol of $( \pm)-1$ or $( \pm)-3,150 \mathrm{rpm}, 26^{\circ} \mathrm{C}$, time. Extraction: $3 \times 20 \mathrm{~mL}$ of ethyl acetate. Co-solvent: dimethyl carbonate. ${ }^{\mathrm{b}}$ These reactions occur directly in YPD.

\section{CONCLUSION}

The Rhodotorula sp was able to make the reduction of $( \pm)-1$ and oxidation of $( \pm)-2$, although with low yields.

\section{ACKNOWLEDGEMENTS}

UNIFESP, FAPESP, CAPES, CNPq.

\section{REFERENCES}

${ }^{1}$ El-Tahir, A. et al. Phytother. Res. 1999, 13, 474. ${ }^{2}$ Andrade-Neto, V. F. et al. Antimicrob. Agents Chemother. 2007, 51, 2346. ${ }^{3}$ Garcia-Urdiales, E.; et al. Chem. Rev. 2005, 105, 313. ${ }^{4}$ Poliakoff, M.; et al. Science 2002, 297, 807. ${ }^{5}$ Matsuda,T.; et al.Tetrahedron-Asymmetry, 2009, 20, 513. ${ }^{6}$ Vukics, K.et al. Org.ProcessRes.Dev.2002,6,82. ${ }^{7}$ Bianco,G.G.Tese de doutorado. Universidade de São Paulo, Brasil, 2008. ${ }^{8}$ Bégué, J.P. et al, J. Chen. Soc. Perkin Trans 1, 1992, 3141

$15^{\text {th }}$ Brazilian Meeting on Organic Synthesis - 15 $5^{\text {th }}$ BMOS - November 10-13, 2013 - Campos do Jordão, Brazil 